\title{
PERLINDUNGAN HUKUM BAGI KONSUMEN ATAS PEMILIKAN RUMAH DARI DEVELOPER DI KOTA MAKASSAR
}

\author{
Muhammad Anies
}

Dosen Fakultas Syariah dan Hukum UIN Alauddin Makassar

\begin{abstract}
In the promotion and supply of housing sales, developers often provide redundant information and explanations to consumers who do not fit the facts. As stated in the brochure master plan / site plan that describes the whole long-term development plan such as the construction of public facilities, social facilities and other supporting facilities. Description of the technical specifications that ensure the quality and reliability of home building, as well as the provision of price discounts or certain gifts. Words or sentences are strung together in a brochure and was very impressed ideal. Moreover, explanation sales marketing (direct selling) is very beautiful by giving exaggerated picture of the development plan, and often gives promises uncertain, revealed weaknesses and degrading product developer competitors. This was done to attract the attention and interest of consumers to decide to buy homes in the developer. Moreover, the current management strategy and marketing as well as media promotion of such a sophisticated but sometimes it is not ethical, all kind of ways to reap profits and gain market share.
\end{abstract}

\section{Keywords:}

Legal Protection, Consumer, Real Estate Developer

\begin{abstract}
Abstrak
Dalam kegiatan promosi dan penawaran penjualan perumahan, seringkali pengembang memberikan informasi dan penjelasan yang berlebihan kepada konsumen yang tidak sesuai dengan fakta. Seperti dalam brosur dicantumkan master plan/site plan yang menggambarkan tentang seluruh rencana pengembangan jangka panjang berupa pembangunan fasum, fasos dan sarana pendukung lainnya. Uraian spesifikasi teknis yang menjamin kualitas dan keandalan bangunan rumah, serta pemberian diskon harga atau hadiah-hadiah tertentu. Kata-kata atau kalimat-kalimat tersebut dirangkai dalam brosur dan terkesan sangat ideal. Terlebih lagi penjelasan sales marketing (direct selling) yang sangat indah dengan memberikan gambaran yang berlebihan tentang rencana pengembangan, bahkan seringkali memberikan janji-janji yang belum
\end{abstract}


pasti, mengungkapkan kelemahan-kelemahan dan merendahkan produk developer pesaingnya. Hal ini dilakukan guna menarik perhatian dan minat konsumen untuk memutuskan membeli rumah tinggal pada pengembang tersebut. Apalagi saat ini strategi dan manajeman pemasaran serta media promosi yang sedemikian canggih namun terkadang tidak beretika, menghalalkan segala macam cara untuk meraup keuntungan dan menguasai pasar.

Kata Kunci:

Perlindungan Hukum, Konsumen, Pengembang Perumahan

\section{A. PENDAHULUAN}

\section{Latar Belakang}

eiring dengan perkembangan pembangunan permukiman yang dibangun oleh developer secara terpadu yang dibarengi dengan derasnya promosi iklan 1 perumahan di berbagai media massa yang menjanjikan berbagai macam bonus dan fasilitas permukiman secara terpadu, mendorong masyarakat lebih cenderung untuk membeli rumah di lokasi permukiman dengan harapan untuk memperoleh kawasan rumah tinggal yang terpadu dengan fasilitas permukiman yang nyaman, aman dan asri dalam lingkungan yang sehat, serasi dan teratur sebagai perwujudan hak setiap warga negara dalam hal ini para konsumen untuk menikmati rumah tinggal yang layak huni dengan segala fasilitas dan lingkungan yang nyaman.

Dalam memperoleh rumah, dari developer dengan cara jual beli, konsumen akan menghadapi berbagai macam bentuk perjanjian yang harus ditandatangani. Perjanjian tersebut diawali dengan perjanjian jual beli di bawah tangan yang biasa disebut Perjanjian Pengikatan Jual Beli (PPJB). Draft perjanjian ini biasanya berbentuk baku (kontrak standar) yang telah dirancang oleh developer, sehingga konsumen tidak mempunyai bargaining position untuk menentukan kehendaknya dalam draft perjanjian tersebut. Perjanjian tersebut hanya siap untuk ditanda tangani. Apabila konsumen setuju maka ia harus menandatanganinya, meskipun tampaknya hak-hak konsumen dalam draft PPJB tersebut tidak begitu jelas. Bahkan sering dimuat klausula-klausula pengecualian (exemption clause) seperti: meniadakan tanggung jawab developer dalam hal terlambat menyerahkan bangunan, sebaliknya bila konsumen terlambat membayar angsuran uang muka atau melunasi harga rumah, dikenakan penalti atau denda; membebaskan developer dari klaim atas kondisi/kualitas bangunan yang melampaui batas waktu 100 (seratus) hari sejak serah terima bangunan fisik rumah dan sebagainya.

Adapun akses masuk ke komplek perumahan itu, jalan selebar enam meter, dan hanya terdiri atas masing-masing satu lajur. Kawasan perumahan itu dipastikan tidak banjir karena mempunyai kawasan reservasi air dan sistem drainase yang cukup baik. A. Rivai, percaya karena yang membangun real estate itu adalah developer besar yang mempunyai reputasi, apalagi developer perumahan itu pernah 
menjadi pengurus Real Estate Indonesia (REI). Akan tetapi, ketika akhirnya berdiam di kawasan tersebut A Rivai harus memendam kecewa karena janji developer hanya janji kosong. Atap rumah toko (Ruko), bocor-bocor, plafond terkelupas, lantai tegel pecah-pecah, dan sebagian besar kusen pintu dan jendela tuntas dimakan rayap. Fasilitas perumahan yang pernah dijanjikan tidak kunjung dibangun, dan tiap tahun komplek perumahan tersebut menjadi langganan banjir.

Memang, untuk memperoleh dan memiliki sebuah rumah yang nyaman, layak huni, berwawasan lingkungan, bebas sengketa dan memberikan kepastian hukum kepemilikan haknya tidak mudah. Meskipun konsumen telah memilih lokasi permukiman dan memutuskan untuk membayar harga tanda jadi (booking fee) atau uang muka (down payment) atau membayar tunai seluruh harga sesuai yang telah disepakati dalam perjanjian pengikatan jual beli, tetapi di kemudian hari ternyata lokasi permukiman tersebut tidak jelas keberadaannya, karena tidak jarang developer menjual ruko di atas gambar site plan yang telah didesain awal (penjualan secara indent atau preproject selling) tetapi ternyata lahan permukiman tersebut baru akan dibebaskan atau lokasi rencana pengembangan permukiman tersebut masih dikuasai oleh pihak ketiga dan berada dalam keadaan sengketa. Atau, pembayaran booking fee atau down payment yang akan dibayarkan konsumen akan digunakan developer untuk membebaskan lahan atau untuk menutupi dan menebus hutang kredit konstruksi di bank.

Selain itu, rencana lokasi pengembangan permukiman telah dibebaskan dan telah tersedia, telah didesain oleh developer dalam rencana master plan atau site plan berupa pemetaan kavling dan gambar type rumah.

Demikian pula sarana dan prasarana pendukung seperti penyediaan sarana air bersih, listrik, tempat pembuangan sampah, jalan, selokan dan drainase, lampu penerang jalan dan sarana lainnya seperti sarana ibadah, olah raga, sarana pendidikan belum atau tidak kunjung di bangun oleh developer sesuai janjinya pada saat penawaran perdana kepada konsumen, dan hengkang begitu saja setelah proyek selesai. Padahal, dalam Permendagri Nomor 1 tahun 1997 ditegaskan bahwa dalam mengembangkan suatu kawasan permukiman pengembang harus menyediakan prasarana lingkungan, fasilitas umum (fasum) dan fasilitas sosial (fasos).

Selain itu, banyak pula developer tidak mempedulikan pelayanan purna jual dan pengelolaan lingkungan setelah rumah dan sertifikat tersebut diserahkan dan dialihkan kepada konsumen. Seperti penyediaan dan pengelolaan sarana air bersih, pemeliharaan lampu penerangan jalan, perbaikan dan pemeliharaan jalan serta selokan sehingga menimbulkan banjir, pemeliharaan taman dan ruang terbuka hijau, sarana pengamanan (satpam) dan sarana-sarana pendukung lainnya. Padahal, pelayanan purna jual dan pengelolaan lingkungan ini adalah bagian dari kewajiban developer dan merupakan hak bagi konsumen.

Permasalahan tersebut di atas sebenarnya tidak perlu terjadi bila Kepmenpera 
No. 09/KPTS/M/1995 dipatuhi oleh developer, seperti: kewajiban melaksanakan pendirian bangunan sesuai waktu yang telah diperjanjikan menurut gambar arsitektur, gambar denah, dan spesifikasi teknis bangunan; menyelesaikan pendirian bangunan dan menyerahkannya sesuai waktu yang diperjanjikan; memiliki persyaratan administratif dan perizinan; mengurus pendaftaran perolehan hak atas nama user; membayar denda sebesar $2 \%$ o (dua per seribu) dari jumlah total harga rumah setiap hari keterlambatannya apabila developer lalai untuk menyerahkan tanah dan bangunan rumah sesuai waktu yang diperjanjikan.

Rentannya permasalahan yang dihadapi konsumen atas pemilikan rumah tinggal dan rumah toko, dari developer, sehingga hubungan hukum jual beli seringkali menjadi tidak harmonis, dan bahkan tidak jarang menimbulkan sengketa hukum antara konsumen dengan developer, meskipun pada akhirnya konsumen harus gigit jari karena upaya hukum yang dilakukan justru tidak dapat memberikan perlindungan atas hak-haknya, mengingat posisi developer yang begitu kuat di depan hukum dan institusi hukum.

\section{Permasalahan}

- Bagaimanakah hubungan hukum antara konsumen dengan developer dalam jual beli dan pemanfaatan rumah di kota Makassar?

- Bagaimanakah perlindungan hukum bagi konsumen atas pemilikan rumah, dari developer di kota Makassar?

\section{Tujuan dan Manfaat Penelitian}

Bahwa setiap melakukan penelitian tentu saja harus mempunyai tujuan mengapa penelitian itu dilakukan dan apa kegunaan hasil penelitian itu.

Adapun tujuan penelitian ini dilakukan, dimaksudkan:

a. Untuk mengetahui hubungan hukum antara konsumen dan developer, hubungan hak dan kewajiban antara konsumen dan developer dalam pemilikan dan pemanfaatan rumah, di lokasi permukiman;

b. Untuk mengetahui perlindungan hukum bagi konsumen atas pemilikan rumah yang diperoleh dari developer.

Manfaat Penelitian adalah sebagai berikut:

a. Memberikan masukan bagi masyarakat, calon konsumen, para konsumen, para developer, para kontraktor yang ditunjuk developer, lembaga atau wadah organisasi developer, para penegak hukum dan praktisi hukum.

b. Memberikan perlindungan hukum atas hak-hak konsumen dalam pemilikan rumah, sehingga tercipta suasana bisnis yang kondusif dan saling menguntungkan, dengan tidak mengabaikan hukum sebagai norma-norma dalam hubungan hukum. 


\section{B. TINJAUAN PUSTAKA}

\section{Pengertian Jual Beli}

Sebagaimana yang tertuang dalam Pasal 1457 Kitab Undang-Undang Hukum Perdata (selanjutnya disebut KUHPerdata), diatur bahwa jual beli adalah suatu perjanjian, dengan mana pihak yang satu mengikatkan dirinya untuk menyerahkan suatu kebendaan, dan pihak yang lain untuk membayar harga yang telah dijanjikan.

Hal ini diatur dalam Pasal 1458 KUHPerdata bahwa jual beli dianggap telah terjadi antara kedua belah pihak, seketika setelah orang-orang ini mencapai kata sepakat tentang kebendaan tersebut dan harganya, meskipun kebendaan itu belum diserahkan maupun harganya belum dibayar.

Pengertian jual beli sebagaimana dimaksud di dalam Pasal 1457 KUHPerdata di atas mengandung makna adanya suatu perjanjian, yaitu suatu perjanjian jual beli baik tertulis maupun lisan.

Perjanjian jual beli menurut Salim H.S (2003:49), adalah:

Suatu perjanjian yang dibuat antara pihak penjual dan pembeli. Di dalam perjanjian itu pihak penjual berkewajiban untuk menyerahkan objek jual beli kepada pembeli dan berhak menerima harga dan pembeli berkewajiban untuk membayar harga dan berhak menerima objek tersebut.

Unsur-unsur yang tercantum dalam definisi tersebut adalah:

1. adanya subjek hukum, yaitu penjual dan pembeli;

2. adanya kesepakatan antara penjual dan pembeli tentang barang dan harga;

3. adanya hak dan kewajiban yang timbul antara pihak penjual dan pembeli.

\section{Perjanjian Jual Beli Antara Konsumen Dengan Developer}

Pada dasarnya, pemilikan rumah di lokasi permukiman yang dibangun developer dilakukan dengan prinsip jual beli. Jual beli ini dilakukan dalam bentuk suatu perjanjian jual beli antara konsumen (calon user) dengan developer. Berbeda dengan jual beli pada umumnya, jual beli rumah berupa tanah dan bangunan dari developer wajib dilakukan dalam suatu perjanjian jual beli secara tertulis, yang didahului dengan suatu perjanjian jual beli di bawah tangan berupa perjanjian pengikatan jual beli.

Jika memperhatikan ketentuan mengenai kewajiban penjual dalam lampiran Kepmenpera No.09/KPTS/M/1995 dalam hubungan jual beli rumah tinggal dan perlindungan konsumen atas pemilikan rumah tinggal dari developer, maka kewajiban developer untuk menyediakan sarana dan prasarana serta pengelolaan lingkungan permukiman tidak diakomodasi dalam PPJB.

Selain jual beli secara tunai dalam pemilikan rumah tinggal dari developer, masyarakat yang tidak mampu membeli rumah secara tunai dapat membeli dan memiliki rumah dengan pembayaran melalui fasilitas Kredit Pemilikan Rumah (KPR) dari bank yang ditunjuk oleh developer. Pembayaran harga rumah melalui fasilitas KPR ini merupakan bagian dari sistem atau cara pembayaran lainnya yang 
telah disepakati antara konsumen dan developer yang tercantum dalam salah satu klausula PPJB yang telah ditandatangani sebelumnya.

Penunjukan bank tertentu dalam pemberian fasilitas KPR untuk jumlah plafond kredit tertentu dilakukan atas dasar adanya kerja sama antara developer dengan pihak bank. Kerja sama ini didasarkan oleh adanya ikatan hukum sebelumnya atas pemberian fasilitas kredit tertentu (seperti: Kredit Modal Kerja, Kredit Investasi, Kredit Konstruksi atau Kredit Pemilikan Lahan) oleh bank kepada developer untuk membebaskan lahan atau membiayai pembangunan konstruksi bangunan rumah dan segala fasilitasnya dengan jaminan berupa sertifikat Hak Guna Bangunan (HGB) induk milik developer di atas tanah lokasi rencana pengembangan permukiman yang akan dibangun oleh developer.

Dengan pemberian fasilitas KPR oleh bank yang ditunjuk kepada konsumen ini telah menimbulkan hubungan hukum yang baru antara konsumen dengan pihak bank, yaitu hubungan perjanjian kredit. Bank bertindak sebagai kreditur dan konsumen (nasabah) bertindak sebagai debitur. Dalam perjanjian ini, konsumen akan tunduk dan mengikuti mekanisme hubungan hukum hutang piutang berupa perjanjian pinjam meminjam sebagaimana diatur di dalam Pasal 1754 sampai dengan Pasal 1764 KUH Perdata. Dalam hubungan ini, konsumen diwajibkan membayar sejumlah komponen biaya, seperti biaya KPR (biaya pengikatan kredit dan pengikatan jaminan), serta pembayaran angsuran pokok dan bunga pinjaman sesuai waktu dan jumlah yang telah ditentukan oleh pihak bank.

\section{Perjanjian Jual Beli Rumah (PPJB) dan Perjanjian KPR Merupakan Kontrak Baku}

Dalam hubungan hukum jual beli rumah tinggal antara konsumen dan developer, dan antara konsumen dan pihak bank akan dijumpai berbagai macam perjanjian atau kontrak baku (kontrak standar). Perjanjian atau kontrak baku adalah perjanjian yang hampir seluruh klausulanya sudah dibakukan oleh pemakainya dan pihak yang lain pada dasarnya tidak mempunyai peluang untuk merundingkan atau meminta perubahan. Kontrak baku pada dasarnya sudah dipersiapkan lebih dahulu oleh salah satu pihak. Pada umumnya yang mempersiapkan kontrak baku ini adalah pihak yang mempunyai kedudukan ekonomi lebih tinggi dibandingkan dengan mitra kontraknya.

Dalam praktek jual beli rumah tinggal dari developer, PPJB rumah dan perjanjian KPR telah dirancang dan dibuat secara sepihak oleh developer atau pihak bank sebagai pemberi KPR dalam bentuk kontrak baku (kontrak standar), yang pada umumnya memuat klausula baku.

\section{Perlindungan Hukum Konsumen di Indonesia}

Setiap orang, pada suatu waktu, baik secara sendiri-sendiri maupun berkelompok bersama orang lain, dalam keadaan apapun pasti akan menjadi konsumen untuk suatu produk barang dan/atau jasa tertentu yang diproduksi, 
ditawarkan dan dijual oleh produsen (pelaku usaha).

Dalam keadaan ini pula, tidak jarang konsumen berada pada kedudukan yang lemah dan tidak aman dalam menggunakan barang dan/atau jasa, sehingga bagi konsumen dalam waktu dan keadaan yang bersamaan juga membutuhkan perlindungan hukum

Konsumen pada umumnya lebih lemah, dibandingkan dengan produsen yang relatif lebih kuat dalam banyak hal, sehingga upaya perlindungan terhadap konsumen makin terasa sangat penting dan mendesak. Gerakan perlindungan konsumen akhirnya lahir sebagai cabang hukum baru dalam perkembangan ilmu hukum. Lahirnya cabang hukum baru ini didasari oleh kesadaran konsumen akan posisinya yang semakin lemah.

Pengertian perlindungan konsumen diatur di dalam Pasal 1 angka (1) UUPK yaitu: perlindungan konsumen adalah segala upaya yang menjamin adanya kepastian hukum untuk memberi perlindungan hukum kepada konsumen.

Rumusan hak-hak konsumen secara garis besar menurut Ahmadi Miru (2000:139) dapat dibagi dalam tiga prinsip dasar, yaitu:

1. hak yang dimaksudkan untuk mencegah konsumen dari kerugian, baik kerugian personal, maupun kerugian harta kekayaan;

2. hak untuk memperoleh barang dan/atau jasa dengan harga yang wajar;

3. hak untuk memperoleh penyelesaian yang wajar terhadap permasalahan yang dihadapi.

\section{Keseimbangan Perlindungan Konsumen dan Pelaku Usaha}

Lahirnya UUPK pada dasarnya antara lain dimaksudkan untuk memberikan kedudukan yang seimbang antara pelaku usaha dan konsumen. Keseimbangan ini merupakan salah satu asas yang terkandung di dalam Pasal 2 UUPK, bahwa: perlindungan konsumen berasaskan manfaat, keadilan, keseimbangan, keamanan dan keselamatan konsumen, serta kepastian hukum.

Di dalam penjelasan Pasal 2 UUPK disebutkan bahwa asas keseimbangan dimaksudkan untuk memberikan keseimbangan antara kepentingan konsumen, pelaku usaha, dan pemerintah dalam arti materiel maupun spiritual.

Keseimbangan perlindungan konsumen dengan produsen, dapat dicapai dengan meningkatkan perlindungan terhadap konsumen, karena posisi produsen yang selama ini lebih kuat dari pada konsumen (Ahmadi Miru, 2000:128).

\section{METODE PENELITIAN}

\section{Lokasi Penelitian}

Banyaknya permukiman yang dibangun oleh developer di kota Makassar yang dipicu oleh jumlah developer yang cukup besar, sehingga bagi calon peneliti menentukan dan mengarahkan sasaran penelitian pada developer yang dianggap sudah lama dan eksis dalam pengembangan permukiman di kota Makassar. Demikian pula jumlah unit rumah yang telah dibangun, dijual dan dihuni 
masyarakat kota Makassar yang cukup besar, serta organisasi perusahaan yang cukup mapan, jaringan kerja sama dengan lembaga-lembaga pembiayaan (perbankan) dalam melakukan eksvansi pembangunan pengembangan permukiman serta pemberian fasilitas Kredit Pemilikan Rumah (KPR) kepada masyarakat.

\section{Jenis dan Sumber Data}

Dalam pelaksanaan penelitian ini akan diperoleh dan digunakan dua jenis data, sebagai berikut:

1. Data Primer, yaitu data empirik yang diperoleh dan dikumpulkan secara langsung dari developer dan responden di lapangan atau lokasi penelitian, yang diperoleh dengan melakukan wawancara;

2. Data Sekunder, yaitu data yang diperoleh melalui penelusuran dan penelaahan studi pustaka, berupa buku, dokumen, peraturan perundang-undangan, majalah, karya ilmiah dan hasil penelitian serta sumber-sumber lainnya yang relevan dengan masalah dan objek penelitian yang akan diteliti.

\section{PEMBAHASAN}

\section{Hubungan Hukum Antara Konsumen Dengan Developer Dalam Jual Beli dan Pemanfaatan Rumah di Kota Makassar}

Pasal 1233 KUH Perdata mengatur bahwa tiap-tiap perikatan dilahirkan baik karena perjanjian maupun karena undang-undang, sehingga dengan perbedaan tersebut juga telah membedakan akibat hukum antara hubungan hukum yang lahir karena perjanjian dan hubungan hukum yang lahir karena undang-undang.

Akibat hukum suatu perikatan yang lahir dari perjanjian memang dikehendaki oleh para pihak, karena memang perjanjian didasarkan atas kesepakatan, yaitu persesuaian kehendak antara para pihak yang membuat perjanjian. Sedangkan akibat hukum suatu perikatan yang lahir dari undang-undang mungkin tidak dikehendaki oleh para pihak, tetapi hubungan hukum dan akibat hukumnya telah ditentukan oleh undang-undang, baik ketentuan hukum yang diatur di dalam KUHPerdata maupun norma-norma hukum yang tersebar di luar KUHPerdata yang bersifat hukum publik, namun pengaturannya bersifat keperdataan.

Salah satu norma hukum yang mengatur hubungan hukum di luar ketentuan KUHPerdata yaitu norma-norma hukum yang diatur dalam Undang-Undang Perumahan dan Permukiman serta Undang-Undang Nomor 8 Tahun 1999 tentang Perlindungan Konsumen (UUPK).

Dalam kaitannya dengan perlindungan hukum bagi konsumen, di dalam UUPK telah diatur berbagai norma-norma hubungan hukum antara konsumen dengan pelaku usaha. Norma-norma hubungan hukum dalam UUPK ini telah memberikan kedudukan yang seimbang antara pelaku usaha dan konsumen. Norma-norma tersebut sekaligus merupakan norma-norma perlindungan kepada konsumen dalam hubungan hukum dengan pelaku usaha, yang menurut Yusuf Shofie (2003:10) dikelompokkan sebagai berikut: 
1. Kegiatan produksi dan/atau perdagangan barang dan/atau jasa;

2. Kegiatan penawaran, promosi, dan periklanan barang dan/atau jasa;

3. Kegiatan transaksi penjualan barang dan/atau jasa;

4. Kegiatan pasca transaksi penjualan barang dan/atau jasa.

Dalam hubungan hukum jual beli dan pemanfaatan rumah tinggal antara konsumen dan developer, pengelompokan norma-norma tersebut tercermin dalam setiap tahapan atau proses hubungan hukum, yang meskipun hubungan hukum jual beli rumah tinggal antara konsumen dan developer didasarkan pada suatu perjanjian (perjanjian jual beli), namun ketentuan-ketentuan di dalam UndangUndang Perumahan dan Permukiman serta UUPK tidak dapat dikesampingkan begitu saja sebagai norma-norma hukum perikatan yang lahir dari undang-undang yang berlaku sebagai hukum publik.

Hubungan hukum jual beli rumah tinggal antara konsumen dan developer merupakan salah satu objek kajian hukum perikatan dengan persoalan hukum yang sangat kompleks, yang tidak hanya terjadi pada skala nasional tetapi juga sudah menjadi persoalan pada masing-masing daerah di mana lokasi permukiman dikembangkan oleh developer.

Kota Makassar merupakan salah satu daerah pengembangan wilayah permukiman yang cukup pesat. Hubungan hukum jual beli rumah tinggal di daerah ini cukup signifikan karena didorong oleh tingginya tingkat urbanisasi masyarakat untuk bermukim sekaligus berinvestasi di daerah ini, baik yang berasal dari daerahdaerah sekitar Makassar dalam wilayah Sulawesi Selatan maupun daerah di luar Sulawesi Selatan pada umumnya, seperti: daerah Jawa (Jakarta), Kalimantan, Ambon, Irian Jaya dan bahkan dari mancanegara, seperti: Belanda, Jepang dan Malaysia.

Kawasan permukiman yang dibangun di wilayah perbukitan kota Makassar dan Moncongloe Lappara Maros ini dibangun dengan konsep rumah alam tanpa pagar. Permukiman dengan konsep tanpa pagar dimaksudkan untuk memberikan apresiasi rumah hunian yang menyatu dengan kondisi alam perbukitan, sehingga diberi nama Bukit Baruga atau rumah diperbukitan.

Pemilik tanah maupun pihak ketiga yang akan melakukan kegiatan usaha baik sejenis maupun tidak sejenis yang belum atau tidak mendapat izin prinsip dari Pemerintah Kota/Daerah setempat tertutup kemungkinan untuk melakukan kegiatan usaha, tentu saja asumsi ini tidak benar oleh karena tidak demikian prinsip diberikannya rekomendasi tersebut.

Dengan diberikannya rekomendasi izin prinsip ini, menjadi dasar bagi developer untuk mengajukan permohonan izin lokasi pada Kantor Pertanahan setempat.

\section{a. Izin Lokasi}

Setelah izin prinsip diberikan dan dimiliki developer, maka selanjutnya 
developer harus menentukan lokasi mana yang akan dijadikan prioritas pengembangan permukiman/ perumahan dalam rangka melakukan kegiatan pengadaan tanah. Izin prinsip yang telah dimiliki selanjutnya ditindaklanjuti dalam bentuk izin lokasi atas wilayah tanah yang akan dibebaskan. Lokasi yang menjadi rencana prioritas pengembangan tidak boleh keluar dari wilayah izin prinsip yang diberikan.

Untuk memperoleh izin lokasi ini, developer harus mengajukan permohonan pada Kantor Pertanahan setempat. Sebelum memberikan izin lokasi, Kantor Pertanahan akan melakukan penelitian (survey) lokasi, apakah lokasi tanah yang akan dibebaskan layak untuk dikembangkan dan tidak memberi dampak bagi masyarakat daerah sekitar, terutama risiko terhadap dampak lingkungan yang ditimbulkannya. Permohonan izin lokasi ini harus dilengkapi dengan hasil survey Analisis Mengenai Dampak Lingkungan (AMDAL) dari Kantor Badan Pengendalian Dampak Lingkungan Daerah (Bapedalda) yang menyatakan bahwa rencana lokasi pengembangan pembangunan permukiman layak untuk dikembangkan.

Sebelum memberikan izin lokasi, Kantor Pertanahan akan melakukan survey lokasi yang dimohonkan, serta membuat peta lokasi tanah yang akan diberikan izin, yang selanjutnya dituangkan dalam suatu keputusan pemberian izin lokasi. Isi surat keputusan Kantor Pertanahan akan dilampiri dengan peta lokasi tanah, dengan syarat dan ketentuan sebagai berikut:

1. Perolehan tanah harus dilakukan secara langsung antara pihak-pihak yang berkepentingan melalui jual beli atau dengan cara pelepasan hak yang dilaksanakan di hadapan Kepala Kantor Pertanahan setempat dengan pemberian ganti kerugian yang bentuk dan besarnya ditentukan secara musyawarah;

2. Pembayaran ganti kerugian tanah serta tanaman tumbuh dan atau bangunan yang ada di atasnya ataupun barang-barang lain untuk pemegang hak atas tanah tidak dibenarkan dilaksanakan melalui perantaraan dalam bentuk dan nama apapun kepada yang berhak;

3. Perolehan tanah harus diselesaikan dalam jangka waktu 12 (dua belas) bulan sejak tanggal ditetapkan surat keputusan pemberian izin lokasi dan dapat diperpanjang paling lama 12 (dua belas) bulan dan dilaporkan perkembangannya oleh penerima izin lokasi kepada Kepala Kantor Pertanahan setempat dengan tembusan kepada Kepala Kantor Wilayah Badan Pertanahan Nasional Propinsi setempat;

4. Untuk tanah yang sudah diperoleh, penerima izin lokasi diwajibkan mengajukan permohonan hak atas tanah kepada pejabat yang berwenang;

5. Jangka waktu berlakunya izin lokasi ini adalah selama 12 (dua belas) bulan sejak tanggal ditetapkannya, dan atas permohonan yang bersangkutan dapat diperpanjang satu kali untuk masa waktu 12 (dua belas) bulan.

Persoalan yang kemudian timbul dengan diberikannya izin lokasi ini adalah timbulnya asumsi penguasaan wilayah rencana pengadaan tanah oleh developer, 
sehingga masyarakat yang tidak mengerti hukum dengan terpaksa harus melepaskan haknya kepada developer dengan cara jual beli, karena bila tidak, maka developer akan menutup akses daerah setempat. Harga jual beli tanah dengan pemilik tanah tentu saja telah dipatok oleh developer.

Selain bentuk perizinan yang diuraikan di atas, developer juga harus dilengkapi dengan akte pendirian dan anggaran dasar perusahaan serta perubahanperubahannya (jika ada) serta pengesahan akta pendirian dari menteri kehakiman, Surat Izin Usaha Perdagangan (SIUP), Surat Izin Tempat Usaha (SITU), Tanda Daftar Perusahaan (TDP), Nomor Pokok Wajib Pajak (NPWP). Kelengkapan perizinan ini merupakan persyaratan badan hukum yang diperlukan developer dalam hubungannya dengan pihak ketiga dan instansi terkait, seperti: perbankan, kantor Notaris/PPAT/PPATS, Kantor Pertanahan serta kantor perpajakan. Selain pihak ketiga, kelengkapan dokumen ini juga sering diperlukan konsumen dalam hubungannya dengan bank untuk mengajukan permohonan fasilitas kredit dan notaris/PPAT/PPATS untuk melakukan penandatanganan pengalihan hak (akte jual beli).

\section{b. Penyusunan Master Plan dan Site Plan}

Sebelum developer mengajukan dan memperoleh izin prinsip dan izin lokasi, maka rencana induk atau Master Plan harus sudah tersedia, karena merupakan salah satu syarat administratif untuk memperoleh kedua izin tersebut. Master Plan ini berupa gambaran secara umum rencana peruntukan lokasi yang akan dibangun dan dikembangkan developer yaitu untuk pembangunan fasilitas permukiman (peruntukannya 40\%) dan untuk bangunan fisik rumah (peruntukannya 60\%). Dalam Master Plan digambarkan dengan jelas wilayah-wilayah peruntukan lokasi baik untuk bangunan rumah maupun fasilitas yang akan dan harus ada dilokasi permukiman. Master Plan ini juga merupakan media informasi (prospektus ringkas) bagi konsumen untuk mengetahui prospek ke depan rencana pengembangan yang akan dilakukan oleh developer. Selain digunakan sebagai lampiran permohonan permintaan izin, Master Plan juga sering dimasukkan sebagai bagian dari brosur (dicetak bersama brosur) guna memberikan gambaran singkat mengenai rencana jangka panjang yang akan dilakukan developer di lokasi permukiman.

Selain Master Plan maka untuk menggambarkan dan menjelaskan secara rinci bagian-bagian wilayah yang akan dikembangkan maka dibuatkan suatu rencana detil berupa Site Plan. Site Plan ini biasanya digunakan pada saat proses produksi akan dimulai. Seperti untuk memulai membangun bangunan rumah, dalam site plan digambarkan mengenai blok dan nomor rumah, batas-batas kavling, letak/posisi bangunan, carport (garasi), taman, selokan dan jalanan. Site Plan tidak sama lengkapnya dengan Master Plan, karena site plan hanya menggambarkan bagianbagian rencana pengembangan secara detil dan tidak memberikan gambaran secara umum dan global seperti halnya dalam master plan. Site Plan hanya digunakan untuk kepentingan intern developer (bagian teknik dan perencanaan) atau untuk 
kepentingan sebagai syarat untuk mengajukan permohonan KPR di bank bagi user guna mengetahui batas-batas, letak dan luas rumah dalam gambar yang disesuaikan dengan keadaaan lapangan.

Persoalan yang sering terjadi dengan diterbitkannya sertifikat kavling ini, yakni apabila proyek yang dibangun developer di biayai oleh pinjaman bank dengan jaminan sertifikat induk, maka baik sisa luasan sertifikat induk maupun sertifikat pecahan/kavling tersebut harus diserahkan ke bank sebagai jaminan utang, yang meliputi tanah dan seluruh bangunan rumah tinggal yang ada di atasnya, sehingga untuk melakukan pengalihan hak dan meyerahkan bukti hak kepada konsumen, developer harus menempuh proses penebusan terlebih dahulu dengan menyerahkan sejumlah dana kepada bank untuk menarik sertifikat. Hal ini banyak terjadi pada penjualan rumah secara tunai. Nilai tebusan/setoran satu sertifikat kavling pada bank yang harus diserahkan/disetorkan developer tergantung dari kesepakatan dalam perjanjian kredit bank yang disesuaikan dengan besarnya nilai plafond kredit yang diberikan kepada developer.

Proses hukum dalam tahap transaksi sebagaimana diuraikan di atas akan melewati berbagai proses/tahapan perbuatan hukum seperti digambarkan pada bagan berikut:
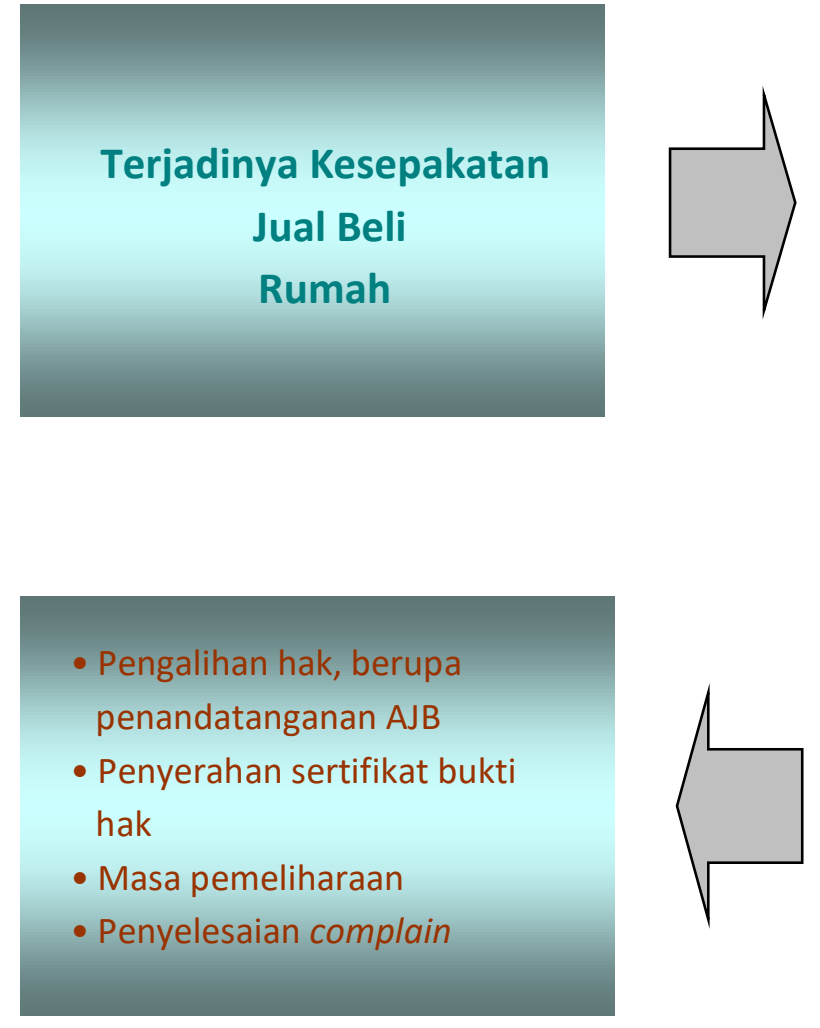

Tahapan perbuatan hukum di atas secara rinci dimuat dan menjadi klausula dalam Perjanjian Pengikatan Jual beli unit rumah. 
a. Perjanjian Pengikatan Jual Beli (PPJB)

Dalam hubungan hukum jual beli rumah antara konsumen dan developer diawali dengan penandatanganan suatu perjanjian jual beli di bawah tangan dengan bentuk Perjanjian Pengikatan Jual Beli (PPJB) atau Perjanjian Pemesanan Rumah (PPR). Hal ini sesuai dengan amanat diktum kedua Kepmenpera No.09/KPTS/M/1995 tanggal 23 Juni 1995), yang menegaskan bahwa: setiap adanya Pengikatan Jual Beli Rumah wajib mengikuti pedoman Pengikatan Jual Beli Rumah beserta contohnya. Contoh perjanjian Pengikatan Jual Beli Rumah sebagai lampiran Kepmenpera No.09/KPTS/M/1995 dapat dilihat pada bagian lampiran tulisan ini.

Bagi konsumen yang terpenting adalah, menandatangani suatu perjanjian jual beli, karena ketiadaan perjanjian tersebut justru akan lebih melemahkan kedudukan konsumen karena tidak adanya ikatan hukum (alat bukti) secara tertulis atas objek perjanjian jual beli yaitu rumah. Umumnya konsumen tidak terlalu mempersoalkan isi dan materi perjanjian selain dari materi tentang harga dan objek jual beli. Penandatanganan perjanjian ini sangat perlu sebagai bentuk adanya hubungan hukum perjanjian antara konsumen dan developer terhadap objek perjanjian.

b. Mekanisme pembayaran

Selain objek jual beli dan harga jual yang diatur dalam PPJB atau PPR, juga ditentukan mengenai mekanisme pembayaran yang harus dilakukan oleh konsumen. Mekanisme atau aturan pembayaran ini meliputi pembayaran tanda jadi (booking fee), uang muka (down payment), dan pelunasan harga, yang dapat dilakukan konsumen dengan cara sesuai yang telah disepakati dan ditentukan dalam PPJB/PPR. Cara pembayaran dapat dilakukan baik secara tunai (cash keras), angsuran/cicilan (cash bertahap), maupun melalui fasilitas Kredit Pemilikan Rumah (KPR) dari bank. Bentuk pembayaran dapat dilakukan konsumen dengan tunai pada kasir developer, menggunakan media surat berharga (cek, bilyet giro), melalui transfer atau inkaso ke rekening bank atas nama developer atau dengan cara melakukan kompensasi pembayaran bagi konsumen yang bermitra usaha dengan developer. Semua bentuk dan cara pembayaran ini dilakukan sesuai kesepakatan dan persetujuan para pihak.

Bagi pembayaran dengan menggunakan fasilitas KPR, umumnya dilakukan melalui bank yang ditunjuk oleh developer, pada PT.BAD KPR harus dilaksanakan pada bank BTN, meskipun pelaksanaan KPR pada bank tertentu ini merupakan hal yang mutlak bagi developer, namun pada PT.BAD dalam pelaksanaan KPR masih memberikan kebebasan bagi konsumen untuk memilih bank sendiri sesuai kehendaknya, seperti pelaksanaan akad kredit/KPR pada bank Danamon, bank Mandiri, bank Bukopin, bank Panin.

Penyerahan pekerjaan pembangunan rumah dari developer kepada kontraktor ini telah menimbulkan hubungan hukum yang baru. Hubungan hukum terjadi dalam bentuk kontrak kerja konstruksi, yang ditandai dengan penandatanganan perjanjian/kontrak kerja konstruksi atau perjanjian pelaksanaan pekerjaan antara 
developer dan kontraktor. Dalam hubungan hukum ini kedudukan developer sebagai pengguna jasa dan kontraktor sebagai penyedia jasa konstruksi. Hubungan hukum dalam kontrak kerja konstruksi ini akan tunduk pada ketentuan hukum perikatan dalam KUHPdt dan Undang-Undang Nomor 18 Tahun 1999 tentang Jasa Konstruksi (Undang-Undang Jasa Konstruksi) juncto Peraturan Pemerintah Nomor 29 Tahun 2000 tentang Penyelenggaraan Jasa Konstruksi.

Perjanjian ini dilampiri dengan syarat-syarat dan kondisi pekerjaan yang harus dilakukan kontraktor berupa gambar dan model rumah, denah dan tampak serta detil bangunan rumah, serta yang paling penting adalah spesifikasi teknis bangunan rumah. Spesifikasi teknis merupakan rencana detil konstruksi dan penggunaan material bangunan rumah, seperti: konstruksi pondasi, struktur beton bertulang, dinding, kusen dan pintu, lantai, plafond dan atap, rangka kayu (atap dan plafond), dapur dan WC, carport dan taman, tempat pembuangan sampah dan selokan, serta penggunaan material seperti semen, batu kali, batu-bata atau batako, kayu (kayu kelas I atau kelas II), keramik lantai, gypsum board atau multipleks untuk plapond, genteng keramik atau seng untuk atap, kunci pintu, instalasi listrik dan air bersih, sanitair, pengecatan, serta berbagai material lainnya untuk finishing interior dan eksterior bangunan rumah.

Jenis, bentuk dan merek material yang digunakan sesuai spesifikasi teknis ini diuraikan secara detil dalam RAB (sebagai lampiran kontrak kerja konstruksi) yang telah dibuat dan disetujui oleh kontraktor dan developer. Rencana detil spesifikasi teknis dalam RAB ini harus sesuai dengan spesifikasi teknis yang dijelaskan dan ditawarkan dalam brosur sesuai type dan harga jual rumah. Spesifikasi teknis ini merupakan unsur yang sangat menentukan kualitas/mutu bangunan rumah.

Uraian spesifikasi teknis dalam brosur merupakan salah satu faktor penting yang dipertimbangkan konsumen dalam memutuskan untuk membeli unit rumah tinggal dari developer. Pekerjaan konstruksi bangunan rumah oleh kontraktor yang tidak sesuai dengan spesifikasi teknis sangat mempengaruhi kualitas/mutu bangunan.

Konsumen yang baik, harus lebih kritis dan sewaktu-waktu mengontrol progress pekerjaan developer atau kontraktor di lapangan. Hal ini dimaksudkan guna menghindari penyelesaian bangunan rumah yang tidak memenuhi spesifikasi teknis. Bila ada material yang tidak sesuai spesifikasi teknis, konsumen harus mengajukan complain kepada developer. Meskipun konsumen mempunyai hak untuk mengajukan complain setelah serah terima rumah dilakukan, namun ada baiknya konsumen mengikuti progress pekerjaan kontraktor, jangan tunggu sampai rumah selesai lalu mengajukan complain, karena risikonya akan lebih berat. Complain lebih awal, lebih baik daripada saat masa maintenance.

Dalam pelaksanaan pekerjaan konstruksi ini, kontraktor selaku penyedia jasa konstruksi kadang bertindak menyediakan dan memberikan layanan jasa perencana konstruksi, pelaksana konstruksi dan pengawasan konstruksi kepada developer 
dengan cara bekerja sama dengan pihak ketiga. Pihak ketiga di sini bertindak sebagai konsultan atau sub kontraktor untuk melaksanakan pekerjaan dari developer bersama-sama dengan kontraktor. Pelaksanaan pekerjaan oleh beberapa pihak ini merupakan bentuk pembagian tanggung jawab dalam pelaksanaan pekerjaan konstruksi bangunan rumah oleh kontraktor. Bentuk pembagian tanggung jawab ini sekaligus dapat menjadi alasan bagi developer atau kontraktor untuk melepaskan tanggung jawab satu sama lain dan membebankan tanggung jawab kepada satu atau lebih sub kontraktor dalam hal terjadi kesalahan yang menimbulkan kegagalan bangunan.

Untuk menghindari rendahnya kualitas bangunan yang dapat menimbulkan kegagalan bangunan selama dalam pelaksanaan pekerjaan bangunan rumah, konsumen mempunyai hak untuk mengawasi pekerjaan kontraktor atau sub kontraktor. Hal ini diatur dalam Pasal 29 Undang-Undang Jasa Konstruksi, sebagai berikut:

Masyarakat berhak untuk:

a. melakukan pengawasan untuk mewujudkan tertib pelaksanaan jasa konstruksi;

b. memperoleh penggantian yang layak atas kerugian yang dialami secara langsung sebagai akibat penyelenggaraan pekerjaan konstruksi.

Meskipun konsumen mempunyai hak complain yang diberikan oleh developer selama masa maintenance setelah bangunan rumah diserahterimakan, namun pengawasan lebih dini selama masa pembangunan rumah ini perlu dilakukan konsumen guna menghindari sengketa yang berkepanjangan dengan developer setelah bangunan diterima.

Dalam masa pemeliharaan ini, konsumen dapat mengajukan complain kepada developer dengan mengisi formulir complain. Konsumen harus mencatat semua kekurangan atau kerusakan fisik bangunan, kesesuaian penggunaan material dan pekerjaan finishing rumah lainnya. Developer wajib melakukan perbaikan-perbaikan atas segala kerusakan atau kekurangan yang diuraikan dalam formulir complain sebagaimana mestinya.

Meskipun konsumen mempunyai hak complain selama waktu yang diberikan, namun masa pemeliharaan akan berakhir sebelum waktunya bila: terjadi pengalihan hak (jual beli) kepada pihak ketiga, konsumen melakukan penambahan atau perubahan bangunan rumah (renovasi). Untuk masa pemeliharaan terhadap jaminan kebocoran atap pada perumahan diberikan untuk waktu satu kali masa/musim hujan berlangsung.

Macam dan bentuk pengaduan yang diajukan konsumen kepada developer pada masa pemeliharaan ini seperti: atap bocor, kusen jendela dan kayu plafond cepat rusak/patah karena kayu yang digunakan tidak sesuai dengan spesifikasi, penyelesaian plamur dan cat, pemasangan instalasi listrik lamban (pengaduan pada PT.BAD), pemasangan keramik lantai tidak bagus/rapi dan retak-retak, tembok retak-retak, genteng bocor pada saat musim hujan, kualitas bangunan tidak sesuai 
spesifikasi, serta keterlambatan penyerahan sertifikat.

\section{c. Pengalihan Hak dan Penyerahan Sertifikat Bukti Hak}

Pengalihan hak ini dilakukan pada saat serah terima bangunan rumah kepada konsumen yang telah melunasi seluruh harga. Pengalihan hak ini ditandai dengan penandatanganan Akte Jual Beli (AJB) di depan Pejabat Pembuat Akte Tanah (PPAT/Notaris atau PPATS/Camat). Dokumen-dokumen yang harus dipersiapkan pada saat penandatanganan AJB ini adalah asli sertifikat objek tanah dan bangunan rumah yang dialihkan (sertifikat HGB atas nama developer), SPPT PBB (kavling atau induk), Kartu Tanda Penduduk (KTP) atas nama pembeli, Akte Pendirian dan Anggaran Dasar serta pengesahannya (developer berbadan hukum), KTP pengurus perseroan yang berhak menandatangani AJB selaku pihak penjual.

Beberapa strategi konsumen dalam mencermati persoalan seperti diuraikan di atas, yakni meskipun konsumen mempunyai dana yang cukup untuk melunasi seluruh harga (tidak menggunakan fasilitas KPR) tetapi ada kekhawatiran bahwa developer nantinya tidak melakukan penebusan seritifikat karena pembayaran konsumen digunakan untuk pembiayaan lain oleh developer, maka konsumen mengajukan permohonan fasilitas KPR dalam jangka waktu pendek (1-12 bulan) hanya dengan maksud agar sertifikat dapat diterima melalui bank dan tidak lagi melalui developer.

Janji yang disampaikan developer pada berbagai media atau sarana tersebut merupakan bentuk informasi yang sangat mempengaruhi dan mendorong keinginan konsumen untuk membeli rumah tinggal di lokasi permukiman yang dibangun developer. Konsumen tentunya telah mempertimbangkan bahwa harga jual unit rumah yang ditawarkan developer sudah termasuk komponen harga sarana dan prasarana yang harus dibayar dalam harga jual, sehingga konsumen menganggap bahwa dengan pembayaran seluruh harga jual sudah meliputi harga/nilai bangunan rumah dan tanah, sarana dan prasarana serta penataan taman dan tanaman.

Anggapan konsumen memang benar, karena umumnya sebelum menetapkan harga jual per unit rumah tinggal (unit price), developer telah memperhitungkan nilai harga pokok (biaya produksi) dan keuntungan (profit margin) kemudian menetapkan harga jual. Harga pokok atau biaya produksi dapat meliputi biaya overhead, harga dan biaya pengadaan tanah, sertifikasi tanah, biaya pemasaran, bunga pinjaman (jika menggunakan fasilitas pinjaman/Kredit Modal Kerja), biaya bangunan rumah, pajak, serta seluruh komponen biaya sarana dan prasarana yang akan dibangun developer (seperti: sarana akses jalan, selokan dan drainase, taman dan tanaman, serta fasum dan fasos lainnya). Harga pokok ini kemudian dikelompokkan ke dalam tiga komponen biaya produksi yaitu biaya bangunan rumah dan tanah (building), biaya sarana dan prasarana (infrastructure) serta taman dan tanaman tumbuh (landscape). 


\section{Perlindungan Hukum Bagi Konsumen Atas Pemilikan Rumah Dari Developer di Kota Makassar}

Perlindungan konsumen adalah segala upaya yang menjamin adanya kepastian hukum untuk memberi perlindungan hukum kepada konsumen (Pasal 1 angka (1) UUPK). Perlindungan hukum merupakan perlindungan atas hak-hak konsumen baik dari pelaku usaha, pemerintah serta institusi hukum dalam kaitannya dengan pemanfaatan atau penggunaan suatu produk barang dan/atau jasa, baik berdasarkan perjanjian maupun menurut peraturan perundang-undangan yang berlaku untuk memberikan jaminan kepastian hukum kepada konsumen sesuai asas perlindungan konsumen.

Untuk mewujudkan perlindungan bagi konsumen, maka perlindungan konsumen diselenggarakan sebagai usaha bersama berdasarkan 5 (lima) asas yang relevan dalam pembangunan nasional (penjelasan Pasal 2 UUPK), yaitu:

1. Asas manfaat dimaksudkan untuk mengamanatkan bahwa segala upaya dalam penyelenggaran perlindungan konsumen harus memberikan manfaat sebesarbesarnya bagi kepentingan konsumen dan pelaku usaha secara keseluruhan;

2. Asas keadilan dimaksudkan agar partisipasi seluruh rakyat dapat diwujudkan secara maksimal dan memberikan kesempatan kepada kosnumen dan pelaku usaha untuk memperoleh haknya dan melaksanakan kewajibannya secara adil;

3. Asas keseimbangan dimaksudkan untuk memberikan keseimbangan antara kepentingan konsumen, pelaku usaha, pemerintah dalam arti materil ataupun spritual;

4. Asas keamanan dan keselamatan konsumen dimaksudkan untuk memberikan jaminan atas keamanan dan keselamatan kepada konsumen dalam penggunaan, pemakaian, dan pemanfaatan barang dan/atau jasa yang dikonsumsi atau digunakan;

5. Asas kepastian hukum dimaksudkan agar baik pelaku usaha maupun konsumen menaati hukum dan memperoleh keadilan dalam penyelenggaraan perlindungan konsumen, serta negara menjamin kepastian hukum.

Dalam hubungan pemilikan rumah dari developer, perlindungan hukum ini dimaksudkan untuk memberikan perlindungan dalam hubungan hukum jual beli dan pemilikan rumah serta perlindungan terhadap hak-hak konsumen untuk menikmati dan memanfaatkan segala sesuatu yang seharusnya diperoleh dalam kaitan jual beli rumah dari developer.

Perlindungan hukum bagi konsumen dalam pemilikan rumah ini juga meliputi perlindungan terhadap pengaduan konsumen sebagai akibat telah terjadinya pelanggaran hak-hak individual konsumen (seperti mutu bangunan di bawah standar, ukuran luas tanah tidak sesuai dan lain-lain), serta pelanggaran hak-hak kolektif konsumen (seperti tidak dibangunnya fasum dan/atau fasos, sertifikasi, rumah fiktif, banjir dan kebenaran informasi dalam iklan, brosur atau sarana promosi lainnya). 
Perlindungan hukum atas hak-hak konsumen di atas, harus diperoleh tiap-tiap konsumen pada setiap proses tahapan transaksi, baik pada tahap pratransaksi (sejak awal proses produksi), tahap transaksi (proses jual beli) maupun pada tahap purna/pascatransaksi (pemanfaatan dan penggunaan rumah tinggal). Perlindungan hukum dalam setiap tahapan transaksi tersebut selanjutnya menjadi norma-norma perlindungan bagi konsumen.

Jika merujuk pada UUPK, proses/tahapan tersebut telah dikelompokkan dalam norma-norma perlindungan konsumen dalam sistem UUPK yang oleh Yusuf Shofie (2003:10), dikelompokan sebagai berikut:

1. Kegiatan produksi dan/atau perdagangan barang dan/atau jasa (Pasal 8 ayat (1), ayat (2), dan ayat (3)) UUPK;

2. Kegiatan penawaran, promosi, dan periklanan barang dan/atau jasa (Pasal 9 ayat (1), ayat (2), dan ayat (3), Pasal 10, Pasal 12, Pasal 13 ayat (1) dan ayat (2), Pasal 15, Pasal 16, serta Pasal 17 ayat (1) dan ayat (2)) UPK;

3. Kegiatan transaksi penjualan barang dan/atau jasa (Pasal 11, Pasal 14, serta Pasal 18 ayat (1), ayat (2), dan ayat (4)) UUPK;

4. Kegiatan pascatransaksi penjualan barang dan/atau jasa (Pasal 25 dan Pasal 26) UUPK.

Pengelompokan norma-norma perlindungan hukum bagi konsumen dalam UUPK yang dilakukan oleh Yusuf Shofie di atas berlaku pula dalam setiap proses/tahapan transaksi jual beli rumah antara konsumen dan developer, yang diuraikan sebagai berikut:

\section{a. Perlindungan Hukum Pada Kegiatan Produksi, Penawaran, Promosi dan Periklanan}

Perlindungan hukum pada kegiatan produksi, penawaran, promosi dan periklanan rumah merupakan proses tahapan pratransaksi, di mana developer baru memulai kegiatan produksi bangunan rumah tinggal yang meliputi pengadaan/penyediaan lahan, pematangan lahan (land clearing atau cut and fill), pengurusan kelengkapan perizinan, penyusunan Master Plan/Site Plan, persiapan arsitektural dan sipil rancangan konstruksi serta pembangunan fisik bangunan rumah.

Produksi bangunan rumah ini selanjutnya akan ditawarkan kepada konsumen (user), baik melalui penawaran langsung (direct selling) maupun dengan menggunakan sarana promosi dan periklanan yang ada (indirect selling). Normanorma perlindungan hukum bagi konsumen pada kegiatan ini diatur di dalam Pasal 8, Pasal 9, Pasal 10, Pasal 12, Pasal 13, Pasal 15, Pasal 16 dan Pasal 17 UUPK. Ketentuan-ketentuan dalam pasal-pasal tersebut berisi larangan bagi pelaku usaha (developer).

Ketentuan Pasal 8 UUPK ini melarang pelaku usaha (developer, kontraktor atau sub kontraktor) membangun atau memproduksi bangunan rumah yang tidak sesuai dengan spesifikasi teknis ataupun kualitas bangunan yang ditawarkan pada 
saat penawaran perdana (direct selling atau indirect selling). Dalam hal pekerjaan bangunan rumah diserahkan kepada kontraktor atau sub kontraktor sebagai mitra usaha developer, maka kontraktor atau sub kontraktor sebagai pelaku usaha penyedia jasa konstruksi (perencana, pelaksana atau pengawas konstruksi) dilarang membangun rumah yang tidak sesuai spesifikasi teknis yang ditentukan dalam Rencana Anggaran Biaya (RAB) yang telah disetujui, mengurangi kuantitas material sehingga mempengaruhi rendahnya kualitas bangunan. Sedangkan developer dilarang memperdagangkan bangunan rumah yang tidak sesuai dengan mutu, tingkatan, komposisi, proses pengolahan, gaya, mode, atau penggunaan tertentu sebagaimana dinyatakan dalam brosur.

Dalam kegiatan produksi, developer dilarang membangun rumah yang tidak dilengkapi dengan izin atau persyaratan administrasi dari Pemerintah Kota/Daerah setempat seperti: rekomendasi izin prinsip, izin lokasi, rekomendasi Analisis Mengenai Dampak Lingkungan (AMDAL), persetujuan dan pengesahan master plan/site plan, izin mendirikan bangunan, dan sertifikat bukti hak.

Meskipun bentuk dan syarat perizinan ini tidak diakomodasi dalam UUPK, namun di dalam Pasal 7 ayat (1) Undang-Undang Perumahan dan Permukiman diatur bahwa setiap orang atau badan yang membangun rumah atau perumahan wajib mengikuti persyaratan teknis, ekologis, dan administratif. Persyaratan teknis berkaitan dengan keselamatan dan kenyamanan bangunan, dan keandalan sarana serta prasarana lingkungannya. Persyaratan ekologis berkaitan dengan keserasian dan keseimbangan, baik antara lingkungan buatan dengan lingkungan alam maupun dengan lingkungan sosial budaya, termasuk nilai-nilai budaya bangsa yang perlu dilestarikan. Sedangkan, persyaratan administratif berkaitan dengan pemberian izin usaha, izin lokasi, dan izin mendirikan bangunan serta pemberian hak atas tanah.

Pembangunan rumah yang sesuai spesifikasi teknis dan kualitas bangunan rumah yang dilengkapi dengan izin atau persyaratan administrasi dari Pemerintah Kota/Daerah serta instansi yang berwenang merupakan bentuk perlindungan hukum kepada konsumen.

Setelah kegiatan produksi selesai, selanjutnya developer akan melakukan serangkaian kegiatan penawaran, promosi dan periklanan untuk memberikan informasi tentang produk bangunan rumah kepada konsumen. Pada kegiatan ini, Pasal 9 UUPK mengatur sebagai berikut:

Ayat (1): Pelaku usaha dilarang menawarkan, mempromosikan, mengiklankan suatu barang dan/atau jasa secara tidak benar, dan/atau seolah-olah:

a. barang tersebut telah memenuhi dan/atau memiliki potongan harga, harga khusus, standar mutu tertentu, gaya atau mode tertentu, karakteristik tertentu, sejarah atau guna tertentu;

b. barang tersebut dalam keadaaan baik dan/atau baru;

c. barang dan/atau jasa tersebut telah mendapatkan dan/atau memiliki sponsor, 
persetujuan, perlengkapan tertentu, keuntungan tertentu, ciri-ciri kerja, atau aksesori tertentu;

d. barang dan/atau jasa tersebut dibuat oleh perusahaan yang mempunyai sponsor, persetujuan atau afiliasi;

e. barang dan/atau jasa tersebut tersedia;

f. barang tersebut tidak mengandung cacat tersembunyi;

g. barang tersebut merupakan kelengkapan dari barang tertentu;

h. barang tersebut berasal dari daerah tertentu;

i. secara langsung atau tidak langsung merendahkan barang dan/atau jasa lain;

j. menggunakan kata-kata yang berlebihan, seperti aman, tidak berbahaya, tidak mengandung risiko, atau efek sampingan tanpa keterangan yang lengkap;

k. menawarkan sesuatu yang mengandung janji yang belum pasti.

Ayat (2): Barang dan/atau jasa sebagaimana dimaksud pada ayat (1) dilarang untuk diperdagangkan.

Ayat (3): Pelaku usaha yang melakukan pelanggaran terhadap ayat (1) dilarang melanjutkan penawaran, promosi dan pengiklanan barang dan/atau jasa tersebut.

Selanjutnya di dalam Pasal 10 UUPK diatur bahwa pelaku usaha dalam menawarkan barang dan/atau jasa yang ditujukan untuk diperdagangkan dilarang menawarkan, mempromosikan, mengiklankan atau membuat pernyataan yang tidak benar atau menyesatkan mengenai:

a. harga atau tarif suatu barang dan/atau jasa;

b. kegunaan suatu barang dan/atau jasa;

c. kondisi, tanggungan, jaminan, hak atau ganti rugi atas suatu barang dan/atau jasa;

d. tawaran potongan harga atau hadiah menarik yang ditawarkan;

e. bahaya penggunaan barang dan/atau jasa.

Dalam kegiatan promosi dan penawaran ini, seringkali developer memberikan informasi dan penjelasan yang berlebihan kepada konsumen yang tidak sesuai dengan fakta yang sebenarnya. Seperti dalam brosur dicantumkan master plan/site plan yang menggambarkan tentang seluruh rencana pengembangan jangka panjang berupa pembangunan fasum, fasos dan sarana pendukung lainnya. Uraian spesifikasi teknis yang menjamin kualitas dan keaandalan bangunan rumah, serta pemberian diskon harga atau hadiah-hadiah tertentu. Kata-kata atau kalimat-kalimat tersebut dirangkai dalam brosur dan terkesan sangat ideal. Terlebih lagi penjelasan sales marketing (direct selling) yang sangat indah dengan memberikan gambaran yang berlebihan tentang rencana pengembangan, bahkan seringkali memberikan janji-janji yang belum pasti, mengungkapkan kelemahan-kelemahan dan merendahkan produk developer pesaingnya. Hal ini dilakukan guna menarik perhatian dan minat konsumen untuk memutuskan membeli rumah tinggal pada developer tersebut. Apalagi saat ini strategi dan manajeman pemasaran serta media promosi yang 
sedemikian canggih namun terkadang tidak beretika, menghalalkan segala macam cara untuk meraup keuntungan dan menguasai pasar.

Berdasarkan ketentuan Pasal 9 dan Pasal 10 UUPK di atas, maka developer harus lebih berhati-hati dalam menggunakan sarana promosi untuk merepresentasikan produknya agar konsumen dapat memperoleh gambaran dan informasi yang benar terhadap produk bangunan rumah yang ditawarkannya. Gambaran, informasi dan representasi produk yang benar merupakan bentuk perlindungan hukum bagi konsumen.

Dalam melakukan kegiatan promosi seringkali developer menawarkan dan menjanjikan pemberian hadiah kepada konsumen, seperti hadiah seperangkat alat dapur, kursi tamu, sofa, tempat tidur atau springbed atau alat-alat rumah tangga lainnya. Pemberian hadiah ini di dalam Pasal 13 ayat (1) UUPK diatur bahwa: pelaku usaha dilarang menawarkan, mempromosikan, atau mengiklankan suatu barang dan/atau jasa dengan cara menjanjikan pemberian hadiah berupa barang dan/atau jasa lain secara cuma-cuma dengan maksud tidak memberikannya atau memberikan tidak sebagaimana yang dijanjikannya.

\section{b. Perlindungan Konsumen Pada Kegiatan Transaksi Penjualan Rumah}

Sebagaimana telah diuraikan sebelumnya bahwa jual beli rumah antara developer dan konsumen ditandai dengan penandatanganan suatu perjanjian pengikatan jual beli, baik model PPJB maupun PPR. Model perjanjian ini adalah baku (kontrak standar) yang telah dirancang dan disusun oleh developer. Dalam menyusun kontrak standar ini, umumnya klausula-klausula dalam kontrak tersebut lebih banyak melindungi kepentingan developer, seperti klausula tentang penerapan denda/penalty bila konsumen terlambat melakukan pembayaran harga, sedangkan bila developer terlambat menyelesaikan dan menyerahkan bangunan rumah kepada konsumen tidak dikenakan denda, bahkan dapat melakukan pembatalan secara sepihak jual beli tersebut tanpa pemberitahuan sebelumnya kepada konsumen. Sedangkan, bila konsumen ingin membatalkan jual beli, maka tanda jadi atau uang muka yang telah dibayarkan konsumen akan dipotong beberapa persen.

\section{E. PENUTUP}

\section{Kesimpulan}

Dari uraian pembahasan sebelumnya, maka hasil penelitian yang diuraikan dalam penulisan tesis ini dapat disimpulkan sebagai berikut:

a. Hubungan hukum yang timbul dalam jual beli dan pemanfaatan rumah antara konsumen dan developer tidak hanya berlangsung karena adanya perjanjian (perjanjian pengikatan jual beli) semata, tetapi juga timbul karena ketentuan undang-undang (hubungan hukum perikatan). Hubungan hukum tersebut berlangsung pada setiap proses/tahapan transaksi, baik tahap pra transaksi, tahap transaksi maupun tahap purna/pascatransaksi, yang dimulai dari kegiatan developer untuk menyediakan berbagai macam kelengkapan perisinan, proses 
produksi (penyediaan dan pemanfaatan lahan untuk pembangunan rumah tinggal beserta sarana dan prasarana), promosi dan penawaran (brosur, iklan.

b. Hubungan hukum tersebut berlangsung pada setiap proses/tahapan transaksi, sehingga perlindungan hukum harus pula diperoleh setiap konsumen dalam setiap tahapan transaksi. Perlindungan hukum atas hak-hak konsumen dalam proses tahapan jual beli dan pemilikan rumah tinggal telah diatur dan tersebar dalam berbagai ketentuan hukum dan perundang-undangan seperti: Kitab Undang-Undang Hukum Perdata, Undang-Undang No. 8 Tahun 1999 tentang Perlindungan Konsumen, Undang-Undang No. 4 Tahun 1992 tentang Perumahan dan Permukiman.

c. Permasalahan sengketa yang seringkali dihadapi konsumen dalam jual beli dan pemilikan rumah, menunjukkan kecenderungan konsumen untuk tidak menggunakan sarana/wadah penyelesaian sengketa yang ada (litigasi dan non litigasi), tetapi lebih cenderung melakukan musyawarah dengan developer.

\section{Saran}

a. Konsumen hendaknya dapat mengetahui hak dan kewajibannya dalam setiap proses/tahapan transaksi, lebih teliti dan cermat dalam melakukan seluruh tahapan hubungan hukum agar terhindar dari berbagai macam permasalahan dan risiko dalam jual beli dan pemanfaatan rumah tinggal.

b. Rentannya permasalahan yang dihadapi konsumen dalam pemilikan rumah dari developer, sedangkan ketentuan hukum dan perundang-undangan belum mengatur secara rinci dan tegas tentang perlindungan konsumen dalam pemilikan rumah tinggal dari developer, sehingga diperlukan upaya regulasi tersendiri untuk mengantisipasi perilaku menyimpang developer yang belum dapat dijangkau oleh hukum.

\section{Daftar Pustaka}

Ahmadi Miru. 2000. Prinsip-Prinsip Perlindungan Hukum Bagi Konsumen di Indonesia. Disertasi. Universitas Airlangga. Surabaya.

Ahmadi Miru dan Sutarman Yodo. 2004. Hukum Perlindungan Konsumen. PT. Raja Grafindo Persada. Jakarta.

Endang Sri Wahyuni. 2003. Aspek Hukum Sertifikasi dan Keterkaitannya dengan Perlindungan Konsumen. PT. Citra Aditya Bakti. Bandung.

Gunawan Widjaja dan Ahmad Yani. 2001. Hukum tentang Perlindungan Konsumen. PT. Gramedia Pustaka Utama. Jakarta.

Husni Syawali dan Neni Sri Imaniyati. 2000. Hukum Perlindungan Konsumen. CV.Mandar Maju. Bandung. 
Nasution, Az. 1995. Konsumen dan Hukum, Tinjauan Sosial, Ekonomi dan Hukum pada Perlindungan Konsumen Indonesia. Pustaka Sinar Harapan. Jakarta.

Parlindungan, A.P. 2001. Komentar atas Undang-Undang Perumahan dan Permukiman $\mathcal{E}$ Undang-Undang Rumah Susun. CV.Mandar Maju. Bandung.

Ronny Hanitijo Soemitro. 1983. Metodologi Penelitian Hukum. Ghalia Indonesia. Jakarta.

Salim, H.S. 2003. Perkembangan Hukum Kontrak Innominaat di Indonesia. Sinar Grafika. Jakarta. 